Original Research Paper

\title{
The Use of Lamtoro Plants as Organic Fertilizers for Cayenne Pepper Plants of Local Varieties (Capsicum frutescens $\mathbf{L}$.)
}

\author{
Nur Aini Bunyani ${ }^{1 *}$, Robert A. Sole ${ }^{2}$, Joritha Naisanu ${ }^{2}$ \\ ${ }^{1}$ Fakultas Mipa Program Studi Biologi, Universitas Persatuan Guru 1945 NTT, Indonesia \\ ${ }^{2}$ Fakultas Pertanian Program Studi Agroteknologi, Universitas Persatuan Guru 1945 NTT, Indonesia
}

\section{Article History}

Received : July $15^{\text {th }}, 2021$

Revised : August $23^{\text {th }}, 2021$

Accepted : September 04 ${ }^{\text {th }}, 2021$

Published : September $14^{\text {th }}, 2021$

*Corresponding Author:

Nur Aini Bunyani,

Universitas Persatuan Guru 1945

NTT,

Kota Kupang NTT ,Indonesia;

Email: jorithanaisanu@gmail.com

\begin{abstract}
Lamtoro is a dry land plant that is widely found in East Nusa Tenggara. The abundant availability of this plant causes this plant to be of no economic value. On the other hand, this plant contains a lot of nitrogen which can be used to supply nutrients for plants, by utilizing the leaf extract.Lamtoro leaf extract can be used as organic fertilizer for chili plants, where this plant has economic value and is in great demand by the public. This study aimed to determine the effect of various concentrations of lamtoro leaf extract which showed the best results on cayenne pepper. This research has been carried out on farmers' land located in the Liliba Family, Oebobo District, Kupang City which took place from April 2020 to July 2020. The design used in this study was a randomized block design (RAK) with 5 treatments and 4 replications, with treatment P0 (control), P1 (administration of 200 ccliter of lamtoro extract concentration of water-1), P2 (administration of 250 ccliter of water-1 extract of Lamtoro concentration). ), P3 (Giving Concentration of Lamtoro Extract 300 ccliter water-1), P4 (Giving Concentration of Lamtoro Extract 350 ccliter water1). The results of this study indicate that the treatment of lamtoro leaf extract has a very significant effect on plant height $(111 \mathrm{~cm})$, number of leaves (221.25 pieces), number of fruit (175.25 pieces), and fruit weight $(128,875$ $\mathrm{kg})$.
\end{abstract}

Keywords: Lamtoro leaf extract, organic fertilizer, Capsicum frutescens L.

\section{Introduction}

Cayenne pepper (Capsicum frutescens L.) is a plant that is very familiar to the people of East Nusa Tenggara which has high economic value (Naisanu, 2014). Cayenne pepper is a horticultural plant, a spice that is widely used for processing various types of food (Cahyono, 2003). Chili contains a variety of compounds that are useful for human health. Sun et al. (2007) reported that chili contains antioxidants that function to protect the body from free radical attacks. Chili also contains Lasparaginase and Capsaicin which act as anti-cancer substances (Kilham 2006; Bano \& Sivaramakrishnan 1980). Chili is a plant that is easy to grow in the lowlands or in the highlands. Chili plants contain lots of vitamin $\mathrm{A}$ and vitamin $\mathrm{C}$ and contain capsaicin essential oil, which causes a spicy taste and provides heat when used for spices (kitchen spices). Chili can be grown easily so that it can be used for daily needs without having to buy it in the market. In line with the high demand for cayenne pepper has an impact on increasing the selling price of chili, namely Rp. $120,000 / \mathrm{kg}$. The high price of chili provides an opportunity for the community to cultivate this plant by using organic fertilizer made from plants typical of the East Nusa Tenggara (NTT) región Naisanu, 2014.

Lamtoro is a dry land plant that is widely found in East Nusa Tenggara. Its abundant availability causes this plant to be of no economic value. On the other hand, this plant contains a lot of nitrogen which can be used to supply nutrients for plants. Lamtoro leaves have nutrients that can be 
used as organic fertilizers to increase soil fertility, loosen hard soil layers and increase $\mathrm{N}$ content which will affect plant growth and development (Thomas, 1992). Lamtoro leaf extract is an organic fertilizer that contains macro and micro nutrients, namely Nitrogen 2.0 - 4.3\%, Phosphorus $0.20-0.40 \%$, Potassium $0.23 \%$, Calcium $2.36 \%$, Protein $30-40 \%$, crude fiber $20-40 \%$ and tannins $10.15 \% \mathrm{mg}$ (Thomas, 1992).

Lamtoro leaf extract in liquid form is easier for plants to use because the elements in it are easily decomposed and not in too many quantities so that the benefits are felt more quickly. Rimungbuloeh (2011) in Simanjuntak (2012), stated that lamtoro leaf extract will stimulate vegetative growth where nitrogen compounds play a role in increasing plant height, number of leaves, leaf area. Furthermore, in plant generative growth, lamtoro leaf extract supplies phosphorus and potassium elements for the flowering and fruit filling process.

The resulth Simanjuntak (2012), showed that lamtoro leaf extract fertilizer with a concentration of 250 liters of water/tan can increase the growth and yield of Packcoy mustard plants. Palimbungan dkk, (2006), In his research, he also stated that a dose of $250 \mathrm{cc}$ liter of water-1 lamtoro leaf extract fertilizer could increase the growth and production of mustard plants. Lamtoro extract will induce or support the growth of plant roots which will supply the nutrients needed by the plant to grow properly. Based on the description above, a research was conducted on "Use of Lamtoro Plants as Organic Fertilizers in the Production of Local Varieties of Cayenne Pepper Plants (Capsicum frutescens L.)". This study aims to determine the effect of giving lamtoro leaf extract on the yield of cayenne pepper.

\section{Materials and Methods}

\section{Place and time of research}

This research was conducted from April to July 2020. The materials used were: black soil, local varieties of cayenne pepper seeds, polybags measuring 50 × $50 \mathrm{~cm}$, trays (nursery), cow dung manure, water, lamtoro leaves. The equipment used are: machetes, blender tools for crushing lamtoro leaves, gembor, scales, meters, buckets, hoes, ballpoint pens and notebooks.

\section{Research design}

The study was conducted using a Randomized Block Design. This study consisted of 5 treatments and 4 replications so that there were 20 experimental units. The experimental unit consisted of 4 polybags so that there were 80 polybags. The treatment is the concentration of lamtoro leaf extract, which consists of:

$$
\begin{aligned}
& \text { P0 : Control } \\
& \text { P1 : Concentration of lamtoro extract } 200 \mathrm{cc} \\
& \text { liter of water }{ }^{-1} \text { polybag }^{-1} \\
& \text { P2 : Concentration of lamtoro extract } 250 \mathrm{cc} \\
& \text { liter of water }{ }^{-1} \text { polybag }^{-1} \\
& \text { P3 : Concentration of lamtoro extract } 300 \mathrm{cc} \\
& \text { liter of water }{ }^{-1} \text { polybag }^{-1} \\
& \text { P4 : Concentration of lamtoro extract } 350 \mathrm{cc} \\
& \text { liter of water }{ }^{-1} \text { polybag }^{-1}
\end{aligned}
$$

\section{Research Implementation}

\section{Seed preparation.}

a. Local varieties of cayenne pepper seeds: chili seeds purchased from farmers are prepared for the next planting process,

b. The seeds to be planted are selected first by soaking them in a container filled with water for 15 minutes, the selected submerged chili seeds are.

\section{Nursery}

Before the chili seeds are planted in polybags, the chili seeds are first sown in the nursery tray for 15 days. The nursery uses Mediterranean soil mixed with organic cow dung in a ratio of 1: 1 .

\section{Preparation of Planting Media.}

The planting medium was black soil cleaned of weeds and mixed with organic cow dung as much as 4 organic cow dung and $6 \mathrm{~kg}$ of soil arranged in blocks with a distance of $50 \mathrm{~cm} \times 50 \mathrm{~cm}$ between replicates.

\section{Preparation of Lamtoro Leaf Extract.}

Lamtoro leaves are taken old leaves, then separated from the stems and weighed, into $30 \mathrm{~g}$ of lamtoro leaves (washed repeatedly until clean) and blended with added $300 \mathrm{ml}$ of clean water, after that filtered and obtained $301 \mathrm{ml}$ and left for 24 hours. Extraction results that have been filtered are put into jerry cans and are ready to be applied to plants in accordance with the predetermined concentration. 
Planting.

Cayenne pepper seedlings aged 15 days after planting were removed from the nursery tray and planted in prepared polybags. Planting is done by inserting 1 cayenne pepper seed per hole.

\section{Maintenance}

After the cayenne pepper is planted, maintenance activities are carried out, namely: watering, weeding, fertilizing and harvesting.

a. Watering.

Watering cayenne pepper plants in each polybag amounted to 1 liter of water, watering was carried out 2 times a day in the morning and evening.

b. Weeding.

Weeding aims to clear the land of nuisance plants (weeds). Weeding is done once a week manually by pulling it out.

c. Fertilization.

The administration of lamtoro leaf extract was carried out when the cayenne pepper plants were 10 DAP, 25 DAP, and 45 DAP according to the dose set on each plant by spraying evenly on the plants. Treatment of concentration of lamtoro leaf extract before application was added with 1 liter of water, each treatment was given 3 times according to the predetermined fertilization time 10 DAP, 25 DAP, and 45 DAP.

Harvest

Chili plants began to be harvested at the age of 95 DAP. Chili fruit was harvested 3 times with an interval of 1 week.Harvesting is done in the morning or evening by picking the fruit along with the stalks one by one until it is finished.

Observation Variables.

Some of the parameters observed are:

1. Plant height $(\mathrm{cm})$.

Plant height measurements were carried out at the time of the first harvest. Measurement is done by measuring from the base of the stem that has been marked to the tip of the highest shoot.

2. Number of leaves (strands).

Observation of the number of leaves was carried out at the time of the first harvest. Observations were made by counting the number of leaves that were fully open, excluding leaves that had turned yellow.

\section{Number of fruit (fruit).}

The number of fruits per plant was obtained by counting the number of fruits at harvest 3 times with an interval of 1 week.

4. Number of fruit (fruit).

The number of fruits per plant was obtained by counting the number of fruits at harvest 3 times with an interval of 1 week.

5. Fruit Weight (kg).

The number of fruits per plant is obtained by weighing the number of fruits at harvest 3 times with an interval of 1 week

Data Analysis Technique.

To determine the effect of giving various concentrations of lamtoro extract on the growth and yield of cayenne pepper plants, the Randomized Block Design (RAK) analysis method was used with a single factor experiment as follows:

$\mathrm{Yij}=\mu+\beta \mathrm{i}+\mathrm{Kj}+\varepsilon \mathrm{ij}$

$(i=1,2,3, \ldots n ; j=1,2,3, \ldots . n)$

Information:

Yij = Observation values on the I-th and j-th treatment.

$\mu \quad=$ General average

$\beta \mathrm{i}=$ Effect of the $\mathrm{i}$-th test.

$\mathrm{Kj} \quad=$ Effect of dosing factor $(\mathrm{P}) \mathrm{j}$ level.

eij $=$ error.

$\mathrm{J}$ If the administration of various doses of lamtoro leaf extract on the growth and yield of cayenne pepper plants showed a significant effect, then proceed with the $5 \%$ Least Significant Difference (BNT) test.

$B N T=t_{\alpha / 2 \text { (dbgala) }} \sqrt{K T_{\text {galat }}\left(\frac{1}{n_{1}}+\frac{1}{n_{2}}\right)}$

\section{Results and Discussion}

\section{Chili Plant Height}

The results of the concentration of lamtoro leaf extract had a very significant effect on the height of the cayenne pepper plant. The average results of observations of cayenne pepper plant height are listed in the following table. 
Table 4.1. Average plant height of cayenne pepper due to the concentration of lamtoro leaf extract.

\begin{tabular}{lc}
\hline Treatment & $\begin{array}{c}\text { Plant height } \\
(\mathrm{cm})\end{array}$ \\
\hline $\begin{array}{l}\text { Control (p0) } \\
\text { Concentration of lamtoro extract }\end{array}$ & $71.5 \mathrm{a}$ \\
$200 \mathrm{cc}$ liter of water ${ }^{-1}$ polybag $^{-1}$ & \\
(p1) & $77.25 \mathrm{~b}$ \\
Concentration of lamtoro extract & \\
$250 \mathrm{cc}$ liter of water polybag $^{-1}$ & \\
(p2) & $88.25 \mathrm{c}$ \\
Concentration of lamtoro extract & \\
300 cc liter of water polybag $^{-1}$ & $97 \mathrm{~d}$ \\
(p3) \\
$\begin{array}{l}\text { Concentration of lamtoro extract } \\
350 \text { cc liter of water }\end{array}$ \\
(p4)
\end{tabular}

The results of the BNT further test showed that the highest average plant height was indicated by the treatment $\mathrm{p} 4$ (concentration of lamtoro extract $350 \mathrm{cc}$ liter of water ${ }^{-1}$ polybag $\left.^{-1}\right)$ and significantly different from other treatments. This is because lamtoro leaf extract contains more $\mathrm{N}$ and $\mathrm{P}$ than other concentrations. Nutrients of $\mathrm{N}$ and $\mathrm{P}$ are needed for apical cell division. The more lamtoro leaf extract given, the more $\mathrm{N}$ and $\mathrm{P}$ nutrients. Primantoro (1999), states that the nutrient $\mathrm{N}$ is needed by plants for the formation of chlorophyll and stimulates vegetative growth of plants such as stems, branches, and leaves. Supardi (1983), said that the nitrogen content will affect the leaves and plant height. According to Goldworthy and Fisher (1992), states $\mathrm{N}$ and $\mathrm{P}$ are useful directly or indirectly in the formation of plant stimulants such as auxin, gibrelin, cytokinin, which are useful in plant growth.

The lowest plant height was found in the control treatment (P0) without giving lamtoro leaf extract. This is because there is no availability of nutrients in the soil so that it has not been able to meet the needs of cayenne pepper plants in their growth. Sutejo (1992), suggested that macro nutrients are needed for the growth of vegetative parts of plants such as roots, stems, and leaves. If the availability of macro and micro nutrients is not sufficient for plants, it will inhibit the growth and development of cayenne pepper plants.

\section{Number of Leaves}

Based on the results of the analysis of the concentration of lamtoro leaf extract on the yield of cayenne pepper, it has a very significant effect on the number of leaves.

Table 4.2. Average Number of Cayenne Pepper Leaves due to the concentration of lamtoro leaf extract

\begin{tabular}{|c|c|}
\hline Treatment & $\begin{array}{c}\text { Number of Leaves } \\
\text { (strands) }\end{array}$ \\
\hline Control (p0) & $136.75 \mathrm{a}$ \\
\hline $\begin{array}{l}\text { Concentration of lamtoro } \\
\text { extract } 200 \mathrm{cc} \text { liter of water }{ }^{-1} \\
\text { polybag }^{-1}(\mathrm{p} 1)\end{array}$ & $164.25 \mathrm{~b}$ \\
\hline $\begin{array}{l}\text { Concentration of lamtoro } \\
\text { extract } 250 \mathrm{cc} \text { liter of water } \\
\text { polybag }^{-1}(\mathrm{p} 2)\end{array}$ & $194.5 \mathrm{c}$ \\
\hline $\begin{array}{l}\text { Concentration of lamtoro } \\
\text { extract } 300 \mathrm{cc} \text { liter of water } \\
\text { polybag }^{-1}(\mathrm{p} 3)\end{array}$ & $211.75 \mathrm{~d}$ \\
\hline $\begin{array}{l}\text { Concentration of lamtoro } \\
\text { extract } 350 \mathrm{cc} \text { liter of water } \\
\text { polybag }^{-1}(\mathrm{p} 4)\end{array}$ & $221.25 \mathrm{e}$ \\
\hline
\end{tabular}

The results of further BNT test showed that the average number of leaves was mostly found in treatment P4 (concentration of $350 \mathrm{cc}$ liters of water ${ }^{1}$ polybag $^{-1}$ ) and was significantly different from other treatments. Nutrient $\mathrm{N}$ is an important nutrient for plants, especially during the early stages of vegetative growth such as the number of leaves. Further explained by Gadner et al (1991), that the formation of vegetative organs requires a number of nutrients, especially nitrogen in sufficient quantities to be used in the formation of carbohydrates and proteins. If the compound is available in sufficient quantities, it will increase the formation of plant vegetative organs. Sugito and Purnama (1998), said that the presence of sufficient $\mathrm{N}$ elements will increase leaf growth. Setyati (1988), states that the availability of sufficient nutrients causes the process of cell division and enlargement to take place rapidly which results in some plant organs growing fast.

The lowest number of leaves was in the $\mathrm{p} 0$ treatment, because in the $\mathrm{p} 0$ (control) treatment, the plants did not receive treatment with lamtoro leaf extract. Plants only got nutrients from the soil whose numbers were not able to increase the number of leaves. $\mathrm{N}$ will affect the growth and development of leaves because $\mathrm{N}$ is an important element in protoplasm and helps the formation of leaves. 
Effendi (1997) suggests that the nutrients needed by plants if they are not available in sufficient quantities allow plants to grow and produce not optimally.

\section{Number of Fruits}

Based on the results of the analysis of variance, various concentrations of lamtoro leaf extract had a very significant effect on the number of fruits. The average results of observations of the number of cayenne peppers are listed in Table 4.3.

Table 4.3 Average number of cayenne peppers due to the concentration of lamtoro leaf extract.

\begin{tabular}{|c|c|}
\hline Treatment & $\begin{array}{c}\text { Number of Fruits } \\
\text { (grams) }\end{array}$ \\
\hline Control (p0) & 75.75 a \\
\hline $\begin{array}{l}\text { Concentration of lamtoro } \\
\text { extract } 200 \mathrm{cc} \text { liter of } \text { water }^{-1} \\
\text { polybag }^{-1}(\mathrm{p} 1)\end{array}$ & $114.75 \mathrm{~b}$ \\
\hline $\begin{array}{l}\text { Concentration of lamtoro } \\
\text { extract } 250 \mathrm{cc} \text { liter of } \text { water }^{-1} \\
\text { polybag }^{-1}(\mathrm{p} 2)\end{array}$ & $145.75 \mathrm{c}$ \\
\hline $\begin{array}{l}\text { Concentration of lamtoro } \\
\text { extract } 300 \mathrm{cc} \text { liter of water } \\
\text { polybag }^{-1}(\mathrm{p} 3)\end{array}$ & $163.75 \mathrm{~d}$ \\
\hline $\begin{array}{l}\text { Concentration of lamtoro } \\
\text { extract } 350 \mathrm{cc} \text { liter of water } \\
\text { polybag }^{-1}(\mathrm{p} 4)\end{array}$ & $175.25 \mathrm{e}$ \\
\hline
\end{tabular}

The results of the further BNT test showed that the average number of fruits was mostly found in the $\mathrm{p} 4$ treatment (concentration of $350 \mathrm{cc}$ liter of water $^{-1}$ polybag $^{-1}$ ) and was significantly different from other treatments. This is because at that dose the nutrient content is more so that it supports generative growth which is characterized by the formation of primordial flowers and developing into flowers. The amount of nutrients, especially $\mathrm{P}$ nutrients which caused more flower development and fruit formation. In line with the opinion of Styorini, (2010) said that the P nutrient is very important in the generative phase, especially for the formation of flowers and fruit formation.

The lowest number of fruit was in the p0 treatment, because in the $\mathrm{p} 0$ treatment (control), the plants did not receive lamtoro leaf extract treatment. few and the number of fruits decreased. According to Ridwan et. al., stated that if the plant does not get $\mathrm{P}$ nutrient then it can affect metabolic activity and can also inhibit the photosynthesis process in relation to the protein content in the leaves, which can cause the increase in the number of fruits to decrease. Darjanto and Satifah (2002), that the transition of plants The generative phase includes the formation of flower buds and the formation of fruit/seeds determined by the nutrients absorbed by the plant. If plants are not given fertilizer intake, the process of fruit formation will be reduced.

\section{Fruit Weight}

Based on the results of analysis of variance, the effect of giving various concentrations of lamtoro leaf extract on the yield of cayenne pepper has a very significant effect on fruit weight. The average results of observations of the number of cayenne peppers are listed in Table 4.4.

Table 4.4 Average Fruit Weight of Cayenne Pepper due to the concentration of lamtoro leaf extract.

\begin{tabular}{|c|c|}
\hline Treatment & $\begin{array}{l}\text { Fruit Weight } \\
\text { (grams) }\end{array}$ \\
\hline Control (p0) & 30.4 a \\
\hline $\begin{array}{l}\text { Concentration of lamtoro } \\
\text { extract } 200 \mathrm{cc} \text { liter of water } \\
\text { polybag }^{-1}(\mathrm{p} 1)\end{array}$ & $56.55 \mathrm{~b}$ \\
\hline $\begin{array}{l}\text { Concentration of lamtoro } \\
\text { extract } 250 \mathrm{cc} \text { liter of water }{ }^{-1}\end{array}$ & \\
\hline polybag $^{-1}(\mathrm{p} 2)$ & $97.625 \mathrm{c}$ \\
\hline $\begin{array}{l}\text { Concentration of lamtoro } \\
\text { extract } 300 \mathrm{cc} \text { liter of water } \\
\text { polybag }^{-1}(\mathrm{p} 3)\end{array}$ & $114.925 \mathrm{~d}$ \\
\hline $\begin{array}{l}\text { Concentration of lamtoro } \\
\text { extract } 350 \mathrm{cc} \text { liter of water }{ }^{-1} \\
\text { polybag }^{-1}(\mathrm{p} 4)\end{array}$ & $128.875 \mathrm{e}$ \\
\hline
\end{tabular}

The results of further BNT test showed that the average number of fruits was mostly indicated by treatment P4 (concentration of $350 \mathrm{cc}$ liter of water1) and was significantly different from other treatments. , the number of fruit is large so that more photosynthate is translocated to the fruit and the fruit is heavier.

Effendi and Muhammad Haris (2011), said that with the fulfillment of nutrients, the process of fruit formation will be optimal and affect the weight of the fruit produced. Koesrini, (2006), stated that lamtoro leaf extract can also contribute decomposer microorganisms into the soil, so that the decomposition process of organic matter in the soil becomes better and can provide plant protein and carbohydrates in fruit formation and fruit weight. 
The lowest fruit weight was in the P0 (control) treatment, this was because the plants only got insufficient nutrients from the soil. According to Hardjowigeno (1987), the addition of organic matter into the soil will increase the supply of macronutrients even in small amounts. According to Nasa (2013), a lack of nitrogen, phosphorus, potassium will cause physiological and morphological changes in plant growth and yields.

\section{Conclusion}

Based on the results of the study, it can be concluded that the administration of lamtoro leaf extract had a significant effect on plant height, number of leaves, number of fruits and fruit weight of cayenne pepper, With the best treatment at a concentration of 350ccliter lamtoro leaf extract water-1(p4) gave the best results on plant height $(111 \mathrm{~cm})$, number of leaves (221.25 pieces), number of fruit (175.25 pieces), and fruit weight (128.875 $\mathrm{kg}$ ).

\section{Acknowledgment}

The author would like to thank the Community Research Institute of the 1945 NTT Teachers Association, which has provided funds for the implementation of this research.

\section{Referensi}

Anonimous (2019). NTT dalam Angka. BPS NTT

Cahyono B. (2003). Cayenne pepper; Cultivation Techniques and Farming Analysis. Yogyakarta: Kanisius.

Cahyono, B. (2003). Green Mustard Cultivation Techniques and Strategies. Yayasan Pustaka Nusantara, Yogyakarta.

Damayanti, Arini Pramesthi (2013). Chemical Content of Liquid Organic Fertilizer from Cow Urine Using PGPR (Plant Growth Promotinga Rhizobacteria) Banana Stem as a substitute for EM4.Thesis.Universitas Muhammadiyah Surakarta

Effendi, Muhammad haris (2011). PGPR (plant Growth Promoting Rhizobacteria).
Gadner, F.P., Pierce, R.B. \& Mitchell, R.L. (1991). Cultivation Plant Physiology. Herawati Susilo translation. Jakarta: UI Press.

Naisanu, J. (2014). Marketing Strategy of Organic Vegetables in Kupang City. Jurnal Cakrawala

Palingbungan, N., Labatar, R dan Hamzah, F. (2006). Effect of Lamtoro Leaf Extract as Liquid Organic Fertilizer on Mustard Plant Growth and Production. Jurnal Agrosistem. Desember 2006, 2 (2)

Rukmana, R. (2002). Cayenne Pepper Farming. Yogyakarta: Penerbit Kanisius.

Sastrosupati, A. (2000). Practical Experiment Design for Agriculture.Kanisius.Yogyakarta.

Setiadi, D. (1990). Types and Cultivation of Cayenne Pepper. Penebar Swadaya Jakarta.

Sutedjo, M. M. (2002). Fertilizer and how to Fertilize.Bineka Cipta. Jakarta.

Setyati, H. (1988). Introduction to Agronomy. Jakarta: ramedia Pustaka Utama.

Setiadi, D. (1990). Types and Cultivation of Cayenne Pepper. Jakarta: Penebar Swadaya

Styorini, et al. (2010). Organic Farming Concept PGPR (Plant Growth romotingRhizobacteria). Surakata: UNS.

Thomas (1992). Agricultural water balance of Yunnan Province. Agroclimatic Zoning with a Geographical Information System. PR China

Widiarti, A. \& Alrasjid, H. (1988). Gmelina arborea (yamane) planting and fertilization techniques Technical information. Bogor: Forest Research and Development Center.

Sugito \& Tugeno (1999). Effect of dose of organic fertilizer azolla and EM4 on growth and yield of caisim plants. In hábitat, 10, 51-58. Faperta Unbraw Malang.

Suwarsono (1980). Soil fertility, Department of Soil Science. IPB Bogor. 